\title{
POLYGONAL KARST MORPHOLOGY OF KARANGBOLONG AREA, JAVA-INDONESIA
}

\author{
MORFOLOGIJA POLIGONALNEGA KRASA OBMOČJA \\ KARANGBOLONG, JAVA, INDONEZIJA
}

\author{
Eko HARYONO ${ }^{1}$, Sutanto TRIJUNI PUTRO ${ }^{2}$, SURATMAN ${ }^{3} \&$ SUTIKNO $^{3}$
}

\begin{abstract}
UDC 551.435.8(594.5)

Eko Haryono, Sutanto Trijuni Putro, Suratman \& Sutikno: Polygonal karst morphology of Karangbolong area, Java-Indonesia

The Karangbolong karst is situated in the southern zone of Java where Miocene limestone has been uplifted and has experienced karstification since the late Pliocene. The research documented here aims at exploring morphological characteristic of the area. Special interest is attributed to differentiation of valley or depression morphology, conical karst morphology, and the roles of jointing system and uplift history in their development. The morphology investigation was mostly undertaken using aerial photograph visual interpretation of panchromatic aerial photograph and analytically shaded DEM, as well as field observations. The results show that the general morphological features of Karangbolong karst are characterized by aligned valleys and aligned enclosed depression with three different patterns. The orientation of the valleys and enclosed depressions coincide with the structural pattern of the area, indicating that the formation of aligned valleys and aligned enclosed depressions is preferential dissolution through jointing. The residual hills are typified by conical karst morphology with sharp peaks. It is found that tight joint spacing appears to be the main reason for the sharp peak of the conical hills. Asides from jointing system, morphology of the area is likely governed also by topographical position and gravity sliding of the limestone bed during the uplift. Uplift history has important control on the differentiation of morphology between plateau part and sloping part. Limitation of this research is that the aerial photograph was not rectified well, because the analyses in this research
\end{abstract}

\author{
Izvleček \\ UDK 551.435.8(594.5) \\ Eko Haryono, Sutanto Trijuni Putro, Suratman \& Sutikno: \\ Morfologija poligonalnega krasa območja Karangbolong, \\ Java, Indonezija
}

Opravili smo geomorfološko študijo območja krasa Karangbolong v južnem delu Jave. Miocenski apnenci tu zakrasevajo od dviga območja v pliocenu. Izpostavili smo razlike med odprtimi dolinami in zaprtimi depresijami, morfologijo stožčastega krasa ter vlogo razpoklinskih sistemov in dvigovanje območja pri geomorfološkem razvoju območja. Metode temeljijo na študiji pankromatskih letalskih posnetkov, senčenega digitalnega modela reliefa ter terenskih raziskavah. Morfološke značilnosti območja se odražajo predvsem v linijski razporeditvi dolin in kotanj. Smer dolin in kotanj sovpada s strukturnim vzorcem območja, kar nakazuje, da je njihov razvoj posledica učinkovitejšega raztapljanja v razpoklinskih conah. Stožčasti vrhovi imajo ostre vrhove, kar je verjetno posledica goste razpoklinske mreže. Na morfologijo območja močno vpliva tudi gravitacijsko drsenje apnenčastih plasti med dvigovanjem ozemlja. Zgodovina dvigovanja je verjetno pomembna za razlike med morfološkimi značilnostmi na pobočjih in planotah. Slabe rektifikacije letalskih posnetkov ne omogočajo dobre morfometrične analize območja, zato smo se omejili predvsem na zaznavanje značilnih geomorfoloških vzorcev.

Ključne besede: Južna Java, kras Karangbolong, poligonalni kras, tropska geomorfologija.

\footnotetext{
${ }^{1}$ Karst Research Group, Faculty of Geography, Gadjah Mada University, North Sekip, Bulaksumur, Yogyakarta, Indonesia, Fax.+622746492340, e-mail: e.haryono@geo.ugm.ac.id

${ }^{2}$ Faculty of Natural Resources Technology, Yogyakarta Institute of Technology, Janti Street Km 4, Yogyakarta, Fax +62274566863 , e-mail: sutanto0612@gmail.com

${ }^{3}$ Karst Research Group, Faculty of Geography, Gadjah Mada University, North Sekip, Bulaksumur, Yogyakarta, Indonesia, Fax.+622746492340, e-mail: ratman_woro@yahoo.com, e-mail: sutikno@geo.ugm.ac.id
}

Received/Prejeto: 14.01.2016 
were more on pattern identification. More accurate rectification is needed for better morphometric analyses.

Key words: Southern Java, Karangbolong karst, polygonal karst, tropical geomorphology.

\section{INTRODUCTION}

Tropical karst morphology, including areas in Indonesia, has drawn the attention of geomorphologists since the early 1900s. It owes its importance through its outstanding residual hill morphology compared to that in other climate zones. High rainfall intensity provides huge dissolution rates for the prerequisite of karstification and karst morphology development. Due to its uniqueness, textbooks on karst geomorphology (Ford \& Williams 2007; Sweeting 1972) gave special attention by putting tropical karst morphology in a separate category. The first publication on Indonesia karst was first made by Lehmann (1936) based on his observation in Gunungsewu karst. His publication then drew several other researchers to get better understanding of Indonesian karst from different perspective (Balazs 1968; Flathe \& Pfeiffer 1965;
Haryono \& Day 2004; Urushibara \& Yoshino 1997). However those publications were based on research conducted in Gunungsewu karst. Different karst areas have not been explored yet, including the Karangbolong karst, though the area is the same physiographic unit as $\mathrm{Gu}$ nungsewu karst.

The Karangbolong karst is situated in the southern zone of Java where the most extensive carbonate rock outcrop in the Java Island is situated. The area is distinguished by an uplifted fault block forming plateau morphology (Bemmelen 1970; Pannekoek 1949). The plateau generally is bordered with an alluvial plain in the north by a fault line scarp. Karangbolong karst itself is a small block of the southern zone of Java covering an approximate area of 4,834 hectares. The area is located

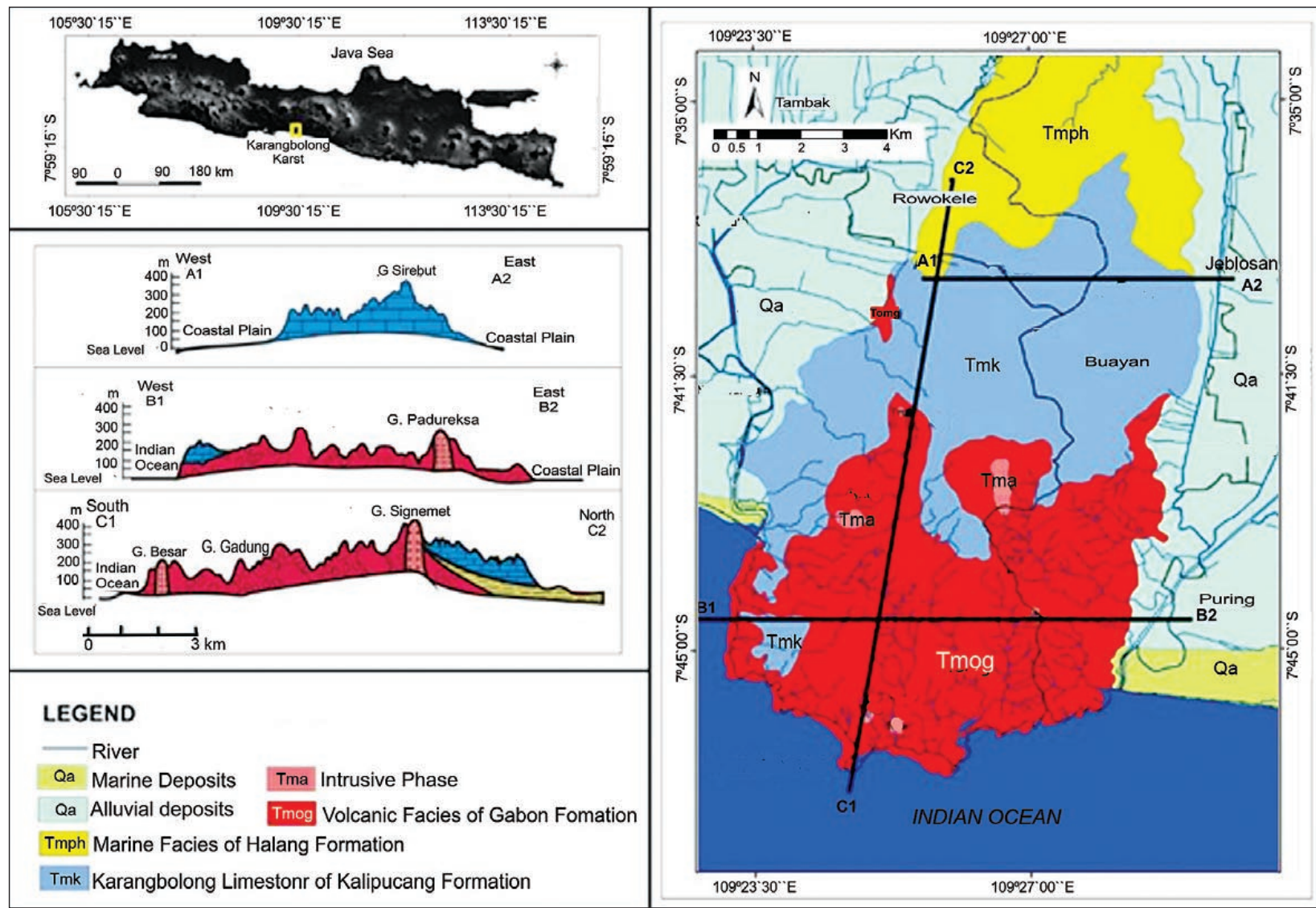

Fig. 1: Geological setting of Karangbolong karst, compiled from Asikin et.al. (1992), Spelman (1979). 
between $106^{\circ} 28^{\prime}-109^{\circ} 14^{\prime} \mathrm{E}$ and $7^{\circ} 38^{\prime}-7^{\circ} 45^{\prime} \mathrm{S}$. The limestone is composed mainly of packstone and boundstone from Kalipucang Formation (Brahmantyo 2005). The Kalipucang Formation is underlain unconformably by the Gabon Formation that comprises mostly volcanic breccia and partly tuff, lava intercalated by sandstone and conglomerate (Asikin et al. 1992). Giving the fact that the Karangbolong karst has been uplifted since the Late Pliocene, the area is geologically considered young. However, karst morphology in the area is already well developed. Cave survey also shows that cave systems have developed very well (Bernard et al. 2003).

The geological setting of Karangbolong karst is considered unique compared to the other karst areas in Java Island. Limestone beds of Karangbolong karst are relatively thin and cover relatively small area. The thickness of the limestone bed is between 300-350 m (Brahmantyo 2005). Being unconformably overlain on the underlying rocks, the limestone of Karangbolong karst is thin in the southern part and becomes thicker to the north. For this reason, most of the underground drainage system of the area flows to the north. Some other underground river systems flow to the west and east to the sloping part of the plateau (Fig. 1).

The mean annual rainfall of Karangbolong area calculated from four nearest rain gauge station during the last 50 year is around 3,000 mm/year (Haryono 2008). Having considerably high annual rainfall with unique geological setting, Karangbolong karst has experienced unique karst development. This paper is an endeavor to explore and analyze morphological characteristic of Karangbolong karst. Special interest will be attributed to differentiation of valley/depression morphology, conical karst morphology, and the roles of jointing system and uplift history in their development.

\section{METHODS}

This research mainly employed 1: 20000 panchromatic aerial photograph interpretations incorporated with DEM-ASTER for slope analyses. Aerial photograph was provided by Bureau of Survey and Mapping Coordination of Indonesia (BIG). Aerial photograph was used for lineaments, closed depression, conical hill peak, and dry valley interpretation. ASTER GDEM with $30 \mathrm{~m}$ resolution was used for examining general morphology of the area and for generating slope map. Since closed depression interpretation was only possible conducted stereoscopically, this research used mirror stereoscope and screen scope interactively for examine the closed depression boundary. The delineation, however, was conducted on screen manually over geometrically corrected scanned aerial photographs using Quantum GIS. Interpretation involved 23 black and white panchromatic aerial photographs. Since aerial photograph has radial errors from the center, only $30 \%$ up to $40 \%$ of the center coverage of the aerial photograph was scanned on $300 \mathrm{dpi}$ and geometrically corrected. Delineation was then used the mosaic of those center coverage of scanned aerial photograph. The geometric correction was conducted through two order polynomial transformation with six up to eight tie points from digital topographic map. Average RMS error found during geometric correction was 4.475. Closed depressions resulted from interpretation were used to analyze closed depression morphometry, i.e. closed depression area, perimeter, length, shape, and pitting index.

\section{RESULTS}

\section{NEGATIVE FORMS (VALLEYS AND ENCLOSED DEPRESSION)}

The negative relief form of the Karangbalong karst is typified by aligned valleys. The formation of the aligned valleys coincides with the general structural pattern of the area, of which the major direction is NW-SE and NE-SW (Fig. 2). These correspond to conjugate joint sets. These two general structural patterns have resulted from compression stresses driven by the northward movement of the subducting India-Australia plate against the Eurasia Plate in the north. The subduction zone of those two plates is situated $200 \mathrm{~km}$ in the south of the study area. Therefore the formation of these valleys could be explained by preferential dissolution along conjugate jointing systems (Fig. 2).

The expression of those structural patterns is varied in different localities. In some parts, the aligned valleys are more clearly depicted in the NE-SW orientation 


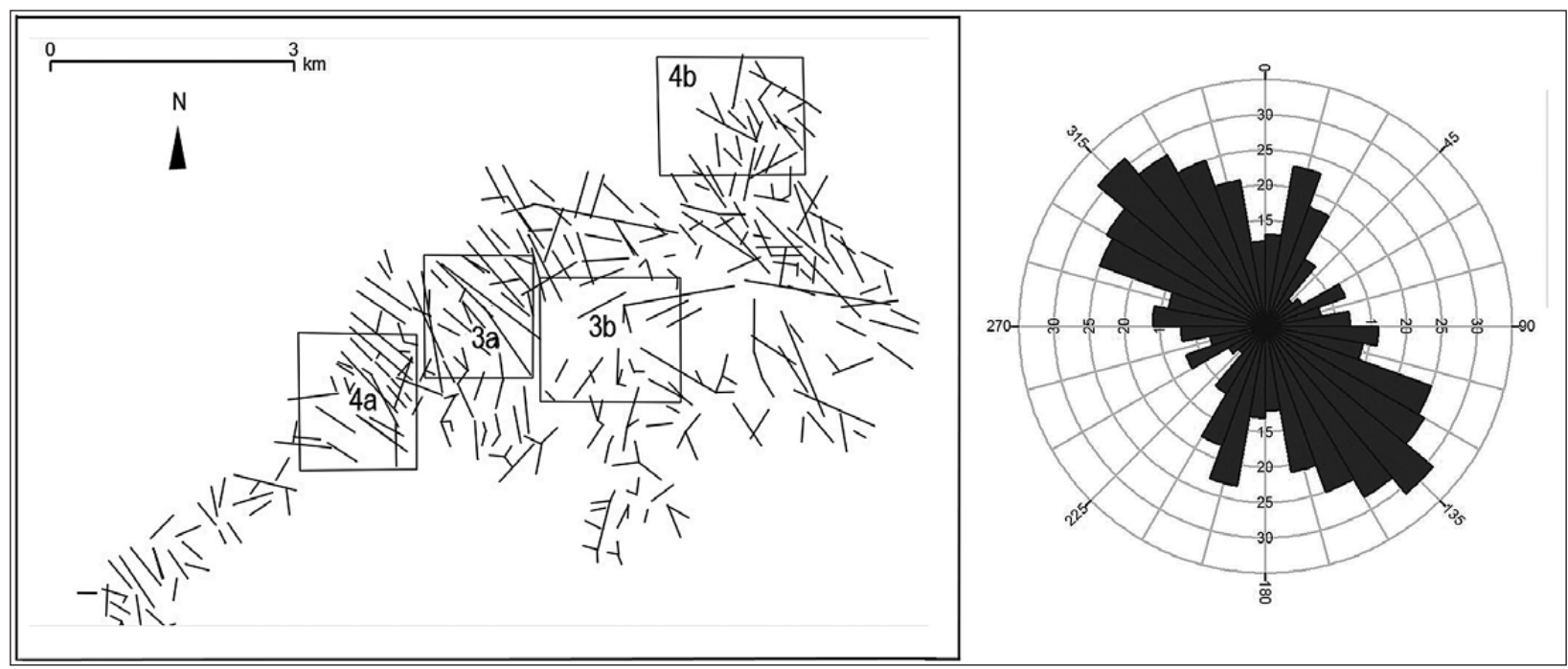

Fig. 2: Lineament and rose diagram of the study area indicating general structural pattern. Box with number are sample areas presented in Fig. 3 and Fig. 4.

(Fig. 3a), whereas in other parts (Fig. 3b), the valleys are depicted prominently in the NE-SE direction. These two different modes are governed by the topographic position of the two localities. NE-SW valleys develop in the northeast part of the Karangbolong karst where the slope trend is heading to the northeast. As such, more surface runoff flows to the northeast resulting in deeper valleys in that direction. On the contrary, the area of Fig. $3 \mathrm{~b}$ is situated in the northwest part of Karangbolong karst where the slope trend is towards northwest. The surface runoff in area of Fig. 3b may have flowed to the northwest direction, in turn forming deeper valley in that direction.

Beside aligned valleys, curvilinear valleys are also found in the Karangbolong karst. Curvilinear valleys are mostly found in the western slope of the Karangbolong plateau. Their origin seems to be related to the collapse and sliding of the limestone blocks during the uplift, as part of detachment tectonics. This collapse and sliding can be shown by the scarp morphology in the upper part of the western slope. The sliding must have caused an outward curvature of the joints that in turn governed the curving preferential dissolution within this area. From the curvilinear pattern, it is likely that during the uplift, the eastern slope of the plateau block glided to the SW direction (Fig. 4a). Radially aligned valleys are also found in the northern slope. This radial pattern is likely governed by interplay of lineament and slope where the summit of the area in Fig. $4 \mathrm{~b}$ is the highest part of Karangbolong karst, and its karst morphology is radially developed from this summit.

More detailed interpretation under a mirror stereoscope revealed that most valleys have already developed into compound enclosed depressions, forming cockpit karst morphology with a polygonal plan view. These polygonal enclosed depressions mostly developed in the southern part and western part of the plateau (Fig. 5). In the sloping part, enclosed depressions do not develop very well. This could be explained by limestone dissolution and erosion by surface runoff rather than concentrated percolation through ponors. Only a few single dolines are found in the area. Single dolines are also found
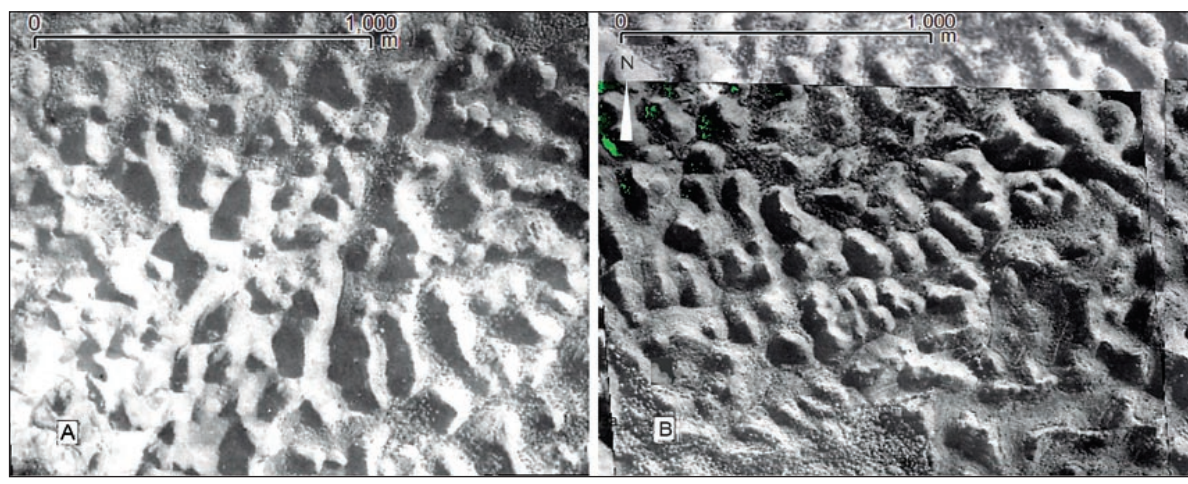

Fig. 3: Aligned valleys in Karangbolong karst indicating NE-SW and NW-SE orientation. These two aerial photographs are situated at box $3 a$ and $3 b$ in Fig. 2 (The aerial photograph courtesy of $B I G)$. 

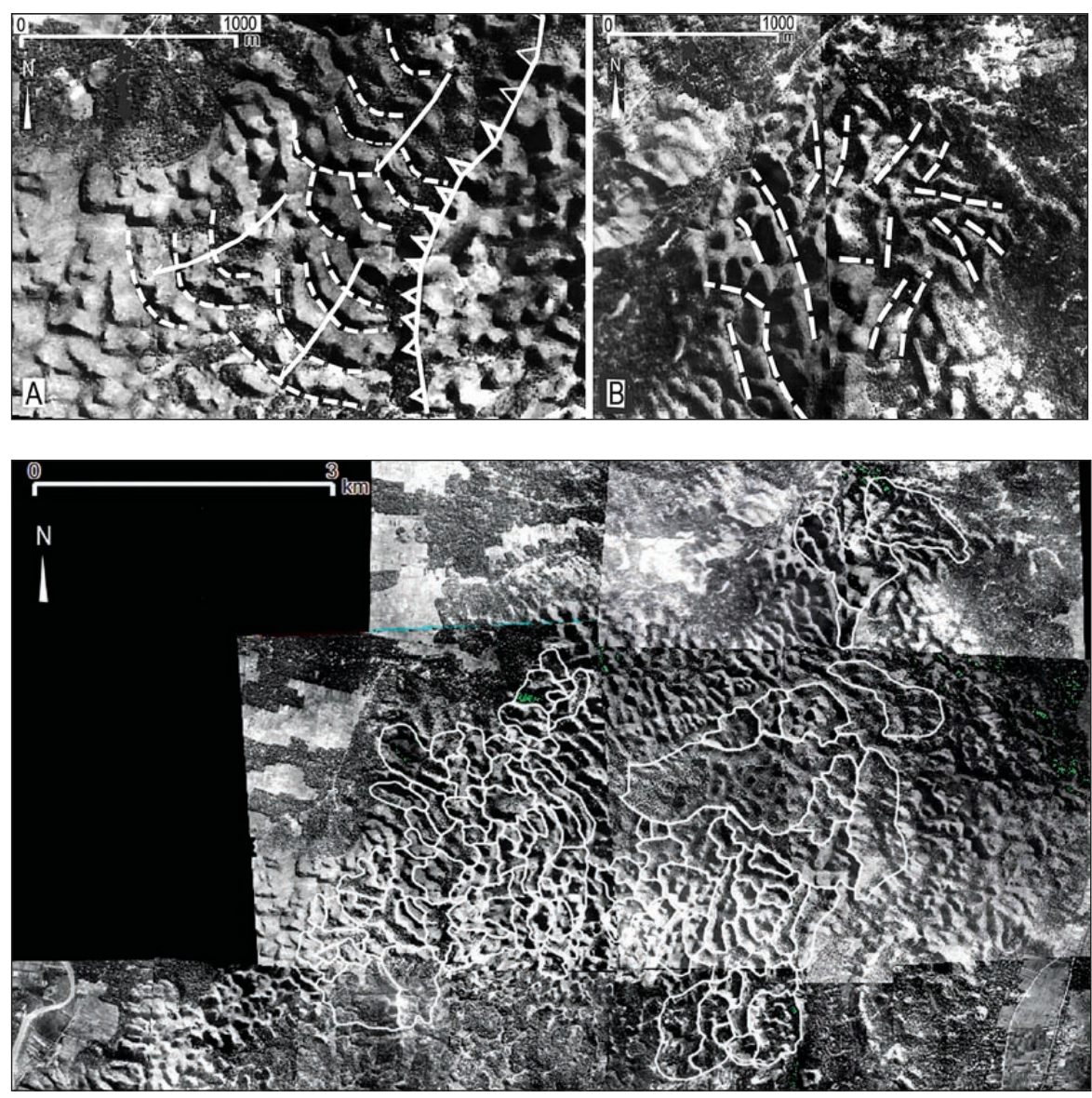

Fig. 4: Two different valley patterns in the western slope (A) and northern slope (B) of Karangbolong karst. In the western slope the valleys are dominated by curvilinear pattern, whereas in the northern slope is more like radial pattern. Solid line with arrow in the figure $A$ is the sliding direction of the limestone during uplift. (The aerial photograph courtesy of BIG).

Fig. 5: Enclosed depression of Karangbolong karst delineated under mirror stereoscope. Due to difficulty of geometric correction processes, the enclosed depression does not precisely match with the overlaid aerial photograph (The aerial photograph courtesy of BIG). in the southern plateau where the limestone is very thin due to shallow underlying volcanic clastic rock. The ratio of closed depression area and limestone area or pitting index (Williams 1971) of Karangbolong karst is 0.76, indicating that the area has been severely karstified. Basic parameters for closed depression morphometry of Karangbolong karst is presented in Tab. 1.

Tab. 1: Closed Depression Morphometry of Karangbolong karst.

\begin{tabular}{l|c|c}
\hline Parameter & Range & Average \\
\hline Area $\left(\mathrm{km}^{2}\right)$ & $0.009-0.584$ & 0.137 \\
\hline Perimeter $(\mathrm{km})$ & $0.371-4877$ & 1.689 \\
\hline Length $(\mathrm{km})$ & $0.137-1.778$ & 0.615 \\
\hline Shape Index & $0.21-0.80$ & 0.44 \\
\hline
\end{tabular}

Closer look at the valley networks the Karangbolong Karst is characterized by multi-basinal and angular drainage pattern (Fig. 6). Compared to that from different karst areas in the world, however, Karangbolong karst has a lower closed depression density. The reason could be explained by the fact that not all depression/valley are enclosed one. Some of the valleys in the sloping part are first order or second order valleys with no sinkholes. On
Tab. 2: Comparison of enclosed depression density in several areas.

\begin{tabular}{l|l|l}
\hline Area & $\begin{array}{l}\text { Enclosed depression } \\
\text { density (depression/ } \\
\mathrm{km}^{2} \text { ) }\end{array}$ & Source \\
\hline $\begin{array}{l}\text { Karangbolong, } \\
\text { Indonesia }\end{array}$ & 5.78 & This study \\
\hline $\begin{array}{l}\text { Gunungsewu, } \\
\text { Indonesia }\end{array}$ & 6.43 & Haryono (2008) \\
\hline New Guinea & $13.05-13.50$ & Williams (1971) \\
\hline Guatemala & 13.1 & Day (1983) \\
\hline $\begin{array}{l}\text { Florida, } \\
\text { Suwannee }\end{array}$ & 6.06 & Denizman (2003) \\
\hline Biokovo, Croatia & 44 & Telbisz et al. (2009) \\
\hline
\end{tabular}

the other hand, angular drainage pattern must be resulted from preferential dissolution through jointing system. Different orders of valleys are encountered in the area. Most of the valley networks (12 as of 15) are first order valley. Only three valley networks have second order valley, and only one valley network has third order valley. Third order valleys are situated in the northern slope of the area. In term of density, the plateau area has lower drainage density than that in sloping part. 

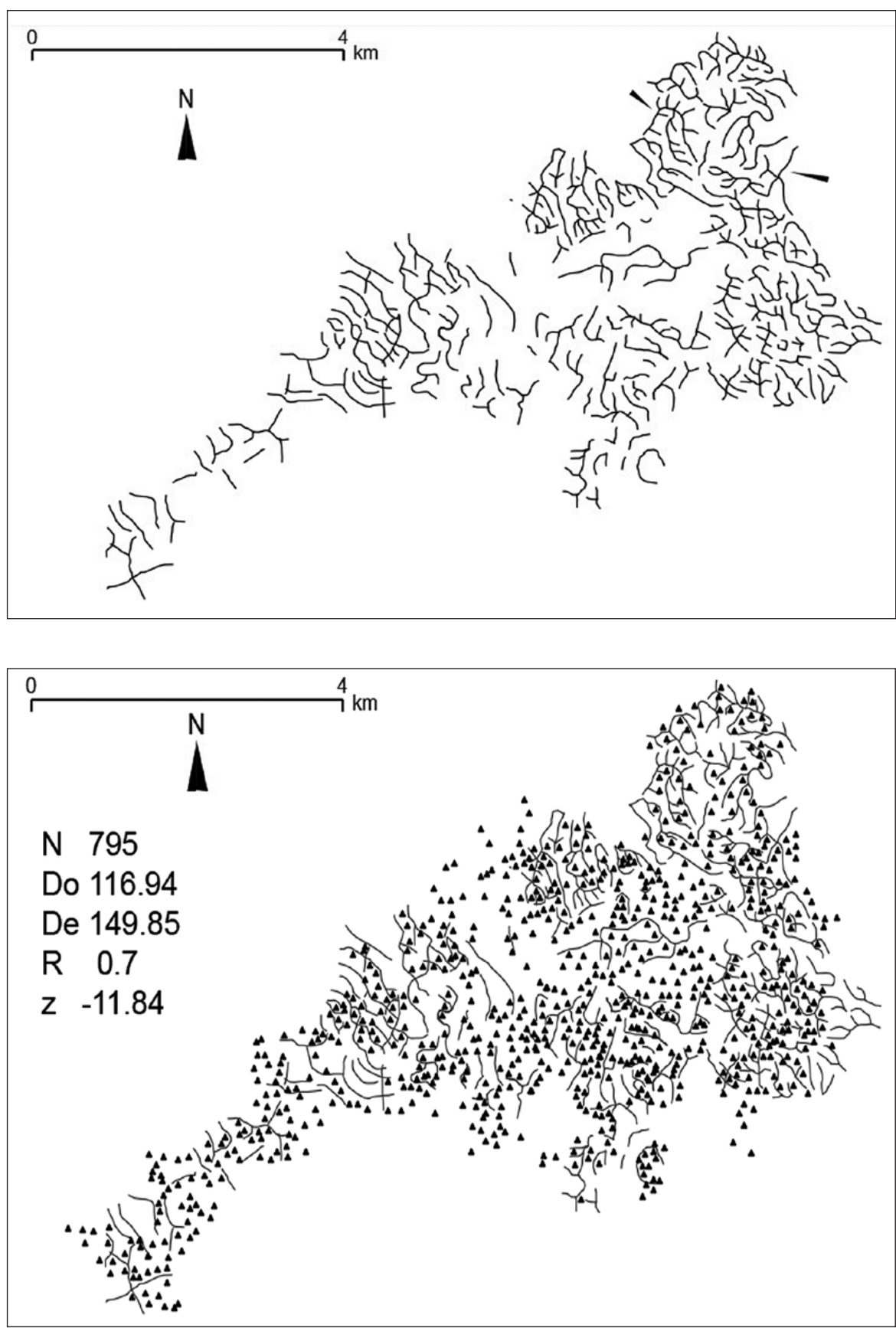

Fig. 6: Drainage of the Karangbolong Kars, black pointers show third order dry valleys.
Fig. 7: Conical karst hills distribution in Karangbolong karst. Conical karst hills are depicted as black triangles, lines are dry valleys. Numbers in the upper left are nearest neighbor parameters: $N$ for number of conical karst hills, Do for mean observed distance $(\mathrm{km})$, De for expected distance $(\mathrm{km}), R$ for nearest neighbor index, and $Z$ for $z$ score.

\section{POSITIVE FORM/RESIDUAL FORM}

The residual form of the Karangbolong karst is typified by cone karst morphology (Fig. 7). Compared to the nearby karst areas in the same southern zone of Java, the cone morphology of Karangbolong karst exhibits sharper peaks instead of rounded cones (Fig. 8). The plan view of the conical hills is more elongated rather than circular. The number of conical karst hills, counted from aerial photographs, is 795 with density of 28 cones $/ \mathrm{km}^{2}$. The distribution of conical karst hills in the area is indicated by a nearest neighbor index (R) of 0.7 , which is in the transition between clustered and random (Fig. 7). The height of the conical karst hills varies from $12 \mathrm{~m}$ up to $72 \mathrm{~m}$ with approximately $37 \mathrm{~m}$ in average $(\mathrm{N}=25)$. The highest cones are situated in the sloping part of the karst and the lower conical hills are distributed on the plateau.

More detailed interpretation from the aerial photographs revealed that there is more complexity in the conical karst morphology. Though in Fig. 7 conical karst hills are depicted as separate peaks, most of the peaks lie 


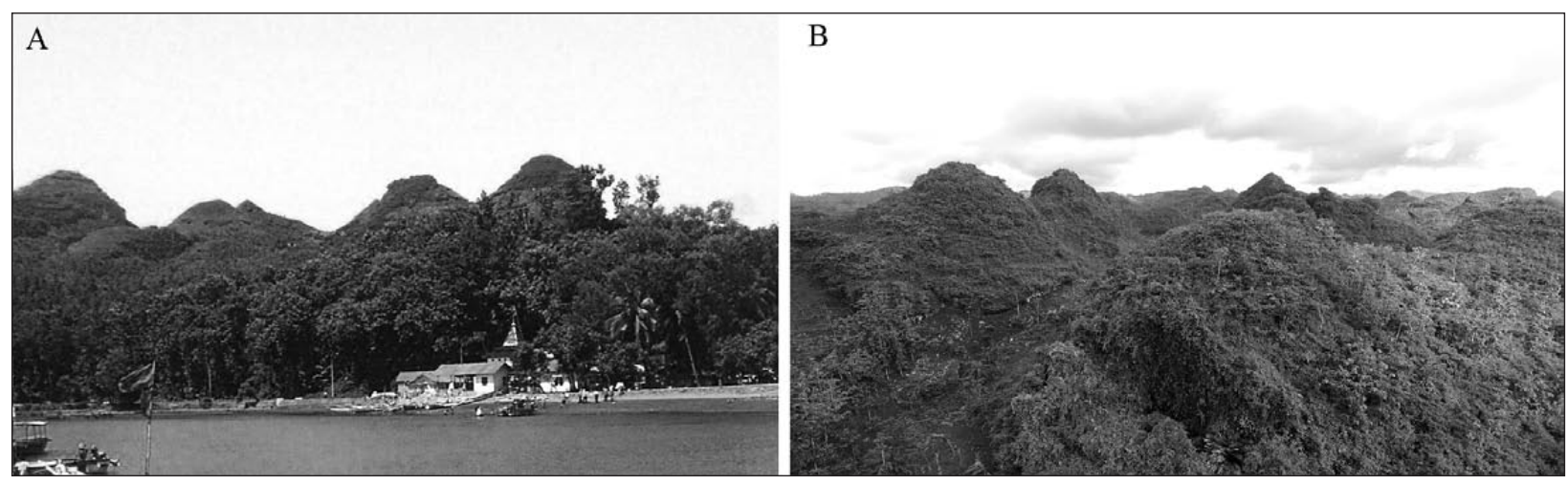

Fig. 8: Conical karst morphology of the Karangbolong karst. The base of the cones is much higher than the base level erosion of the area (A). The cones are mostly organized on ridges separated by aligned valleys (B) (Photo by E. Haryono and S.T. Putro).

on ridges (see Fig. 3 and 4). These elongated hills thus have more than one conical karst peak. Ground view photographs also show more conical hill variation as depicted in Fig. 8. Using further analyses from the $30 \mathrm{~m}$ DEM (ASTER), most of the Karangbolong karst is occupied by flat up to $>65 \%$ slope (Fig. 9). Gentler slopes occupy in the plateau part (0-30\%) and the steeper slope occupies the sloping part surrounding the plateau (31-65\%). As such on the western and eastern slopes, the conical karst hills are higher compared to that in the central part of the plateau. In the central part of the plateau, the conical karst hills are more widely separated with lower relief.

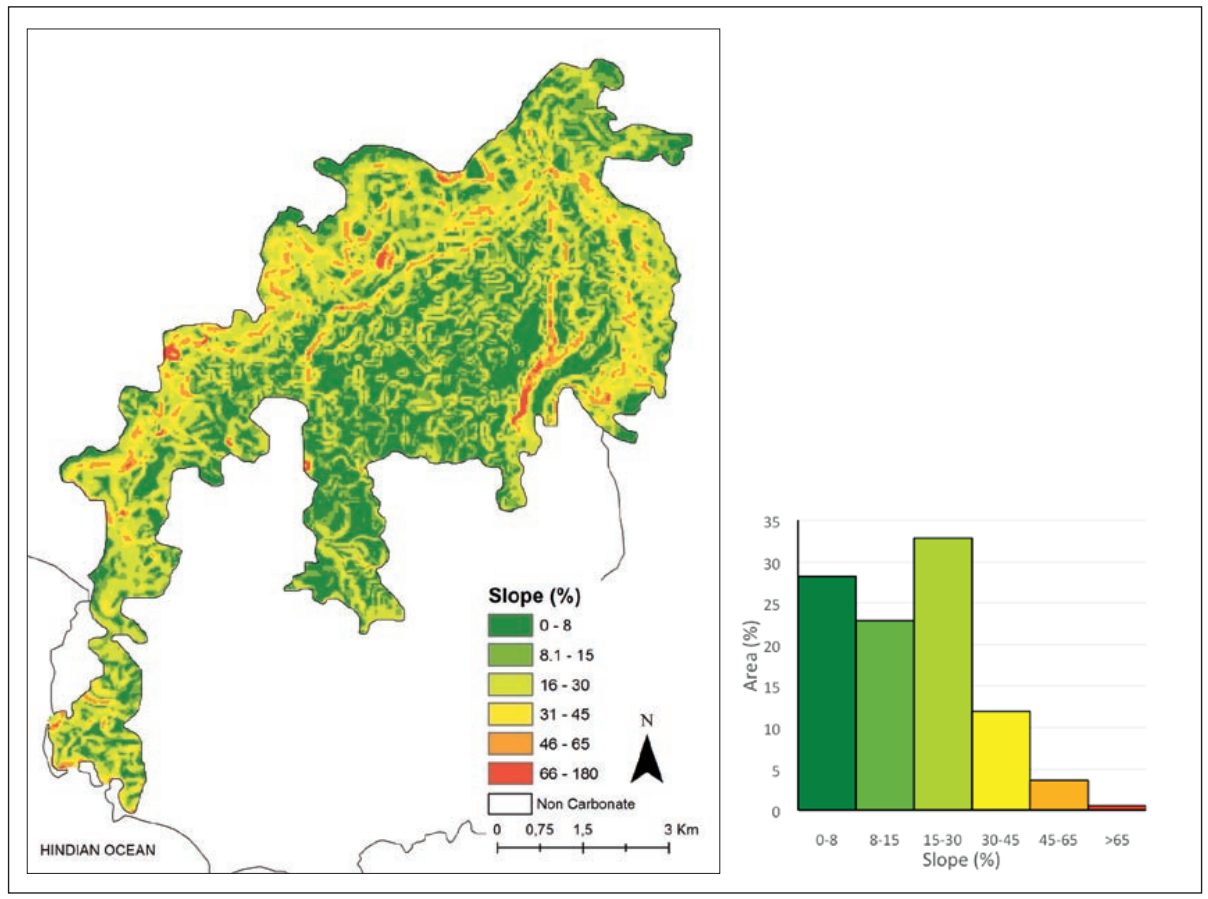

Fig. 9: Slope Distribution in Karangbolong karst. 


\section{DISCUSSION}

The morphology of the Karangbolong karst generally resembles the typical karst of high intensity rainfall areas which are typified by cockpit karst with conical residual hills. The results show that the area exhibits slightly different morphological characteristics governed by jointing system, topographical position, and uplift history and type. There is no evidence that lithological facies has an important role in the morphological differentiation within the area. Previous work by Brahmantyo (2005) suggested that the area is composed of different carbonate facies. Nevertheless, the distribution of the facies does not coincide with the different morphological variation of the karst.

The joint system of the limestone outcrop seems to be the major control of karst morphology. It governs the depression morphology and spacing of the aligned-chain of conical hills that in turn dictate the overall conical karst morphology. Unlike the general karst depression morphology as reported from Papua New Guinea (Williams 1971) or Dinaric Karst (Benac et al. 2013), aligned valleys are readily recognized from aerial photographs or other high resolution remotely sensed imagery. Enclosed depression from aerial photography can really only be recognized under a stereoscope. Joint spacing appears to be the reason for the sharper cone karst compared to neighboring well-known Gunungsewu karst discussed in previous publication (Balazs 1968; Flathe \& Pfeiffer 1965; Haryono \& Day 2004; Lehmann 1936; Tjia 2013; Haryono et al. 2016; Widyastuti and Haryono 2016). Both areas have the same general physiography, climate and carbonate facies. However, the major joints in the Karangbolong area are more closely spaced than that in the Gunungsewu karst. Elongated dolines as described in previous works (Petrović \& Veselinović 2012; Segura et al. 2007) are also very common in the Karangbolong karst.

Topographical position in the area takes an important role in governing the relief magnitude of valleys and conical karst. Higher conical hills, deeper valleys, and steeper slope in the sloping parts can be explained mainly by a higher energy of surface runoff during torrential rainfall. High potential erosional energy during torrential rainfall was also reported by Sweeting (1995) in tropical karst areas of China. Quite often a flash flood takes place in the carbonate outcrops in Indonesian karst where ponors have not yet developed. In this circumstance, mechanical erosion must have played an important role in landform processes. Dissolution processes, though present to some extent, is less prominent than in the plateau part. Surface water generally dries out within an hour after the end of rainfall. Short residence time at the water-rock interface during the torrential rainfall should deter dissolution processes in the sloping part. The dissolution rate, furthermore, significantly increases when the karst valleys are already covered by soils into which slow percolation takes place. As described from different places (Phillips et al. 2004; Segura et al. 2007), hence, the interplay of mechanical erosion and dissolution in sloping part is a considerably more important process in the Karangbolong karst.

Lower conical hills with a wider corrosion plain in the plateau part can be explained by two different possibilities. The first explanation is likely accounted for by a planation process during long periods of limestone exposure during the earliest stage of the uplift history. The second explanation appears to be the reduced erosional and corrosion processes in the upper plateau in contrast to the sloping parts. However the first explanation seems to have more logical basis, since the area has experienced different phases of uplifting. It has been suggested by previous works (Brahmantyo 2005; Haryono 2013; Pannekoek 1949; Urushibara \& Yoshino 1997) that the southern zone of Java in which the Karangbolong karst is situated had experienced uplift in the early Pleistocene continued by prolonged stable tectonic setting. Abrupt uplift then happened in the late Pleistocene giving rise to the present situation and made possible the development of deeper valley in the sloping part through a coupling of backward erosion and corrosion.

The other unique characteristic of morphology differentiation within Karangbolong karst is the morphology inherited from gravity sliding of the limestone beds during uplift. This valley morphology seems to be the first report of such a karst valley pattern. The gravity sliding seems to bend the linear jointing to a curvilinear form that in turn results in curvature depression.

With respect to karst development, the morphological characteristics of Karangbolong karst appear to be in the stage of mature karst. The morphology of the area resemble mature stage development suggested in karst development model (Ahnert \& Williams 1997; Aref et al. 1987; Lehmaann 1936) where karst development starts from joint-controlled dissolution within the plateau. The mature development of Karangbolong karst is also shown by the development of the karst aquifer and mapped cave passages in the area. A well-developed karst aquifer is characterized by the occurrence of diffuse infiltration, internal runoff, sinking streams, and conduit flow found in the area (Haryono et al. 2013). Five major cave systems and underground rivers were found in the area where a conduit aquifer has developed (Bernard et al. 2003; Haryono et al. 2013). However, in 
contrast with mature karst in different areas from Papua New Guinea (Williams 1971) and Croatia (Telbisz et al. 2009), the Karangbolong karst areas does not exhibit ideal cockpit karst morphology. Not all of the karst area is occupied by enclosed depressions (cockpit), but some portion of the karst area is occupied by aligned valleys. The aligned valleys are generally encountered in sloping parts of the plateau.

\section{CONCLUSIONS}

The morphology of the Karangbolong karst is typified by a combination of aligned valleys with conical hills. Though the area is already in a mature stage of karst development, not all of the karst area is occupied by enclosed depressions (cockpits). Differentiation of morphological characteristics in the area was found to be governed by jointing, topographical position, and detachment tectonics during the uplift. The jointing system in the area not only governs the development of aligned valleys and elongate enclosed depressions, but also governs the morphology of conical karst morphology. Tight joint spacing has resulted in the sharp peaks of conical hills. Topographical position governs the differentiation of relief magnitude in the karst morphology. The geological events during the uplift are also found to give some morphological variation in the area. Further attempts should be made to ascertain the control of joint spacing in conical karst morphology by involving more karst areas from different countries and climatic zones.

\section{ACKNOWLEDGEMENTS}

Thanks are due to the editor Dr. Nadja Zupan Hajna, for the English correction and anonymous reviewers for the very constructive comments and suggestion.

\section{REFERENCES}

Ahnert, F.A. \& P.W. Williams, 1997: Karst Landform Development in a Three-Dimensional Theoretical Model.- Z. Geomorphologie, Supplementbände, $108,63-80$.

Aref, E.M.M., Kadrah, A.M. \& Z.H. Lotfy, 1987: Karst Topography and Karstification Processes in the Eocene Limestone Plateau of El Bahariya.- Z. Geomorphologie NF, 31, 1, 45-64.

Asikin, S., Handoyo, A., Pratistho, B. \& S. Gafur, 1992: Geological Map, Banyumas Quadrangle, Java. 1:100 000.- Bandung.

Balazs, D., 1968: Karst Regions in Indonesia.- Karszt-es Barlangkutatas, 5, 3-61.

Bemmelen, R.W. Van, 1970: The Geology of Indonesia. $2^{\text {nd }}$ ed.- Martinus Nijhoff, pp. 732, The Hague.
Benac, Č., Juračić, M., Matičec, D., Ružić, \& I.K. Pikelj, 2013: Fluviokarst and Classical Karst: Examples from the Dinarics (Krk Island, Northern Adriatic, Croatia).- Geomorphology, 184, 64-73. DOI: http:// dx.doi.org/10.1016/j.geomorph.2012.11.016

Bernard, L., Josiane, L., Locatelli, C., Robert, G., Setiawan, R., Sitepu, I. \& F.E.A. Winarto, 2003: Expédition Spéléologique Sur Le Karst de Karangbolong (Java, Indonésie).- Fédération Française de Spéléologie, Report Number: 61.

Brahmantyo, B., 2005: Perkembangan Bentangalam Karst Gombong Selatan, Dengan Geologi Sebagai Faktor Kendali.- PhD thesis. Institut Teknologi Bandung, pp. 182.

Day, M, 1983: Doline Morphology and Development in Barbados.- Annals of the Association of American Geographers, 73, 2, 206-219. DOI: http://dx.doi. org/10.1111/j.1467-8306.1983.tb01408.x 
Denizman, C.A.N., 2003: Morphometric and Spatial Distribution Parameter of Karstic Depression, Lower Suwannee River Basin, Florida.- Journal of Cave and Karst Studies, 65, 1, 29-35.

Flathe, H. von \& D. Pfeiffer, 1965: Grundzuge Der Morphologie, Geologie and Hydrogeologie in Karstgebeit Gunung Sewu/Java Indonesia.- Geol. JB, 83, 533-562.

Ford, D.C. \& P.W. Williams, 2007: Karst Hydrogeology and Geomorphology.- John Wiley \& Sons Ltd, pp. 562, Chicester.

Haryono, E., 2008: Kajian Morfometri Jaringan Lembah Karst Dan Perkembangan Karst Di Kawasan Karst Karangbolong, Karst Gunungsewu, Karst Blambangan, Dan Karst Rengel.- PhD thesis. Fakultas Geografi UGM, pp. 158.

Haryono, E., 2013: Uplift Evidence from Karst Morphology: Preliminary Evidence from Blambangan Peninsula Karst, Indonesia.- In: M. Filippi \& P. Bosák (eds.) Proceedings of the $16^{\text {th }}$ International Congress of Speleology, 21 ${ }^{\text {st }}-28^{\text {th }}$ July 2013, Brno, Czech Republic. Czech Speleological Society, 3, 90-93, Praha.

Haryono, E. \& M.J. Day, 2004: Landform Differentiation within the Gunung Kidul Karst, Java-Indonesia.Journal of Cave and Karst Studies, 66, 2, 62-68.

Haryono, E., Yulianto, B., Putro, S.T. \& F. Nucivera, 2013: Studi Hidrogeologi Kawasan Karst Karangbolong.Fakultas Geografi UGM, Report.

Haryono E., D. Danardono, S. Mulatsih, S.T. Putro \& T.N. Adji, 2016: The Nature of Carbon Flux in Gunungsewu, Java-Indonesia.- Acta Carsologica, 45, 2, 173-185. DOI: http://dx.doi.org/10.3986/ ac.v45i2.4541

Lehmann, H., 1936: Morphologische Studien auf Java.Geographische Abhandlungen, 3, 9, 1-114.

Pannekoek, A.J., 1949: Outline of The Geomorphology of Java.- E.J. Brill, pp. 57, Leiden.

Petrović, A.S. \& R. Veselinović, 2012: The Genesis and Evolution of Uvalas in Gajina Mlaka Paleovalley on the Kucaj Mountains.- Glasnik Srpskog geografskog drustva, 92, 1, 91-104. DOI: http://dx.doi. org/10.2298/gsgd1201091p

Phillips, J.D., Martin, L.L., Nordberg, V.G. \& W.A. Andrews, 2004: Divergent Evolution in Fluviokarst Landscapes of Central Kentucky.- Earth Surface Processes and Landforms, 29, 7, 799-819. DOI: http://dx.doi.org/10.1002/esp.1070
Segura, F.S., Pardo-pascual, J.E., Rosselló V.M., \& J.J. Fornós, 2007: Morphometric Indices as Indicators of Tectonic, Fluvial and Karst Processes in Calcareous Drainage Basins, South Menorca Island, Spain.- Earth Surface Processes and Landforms, 32, 13, 1928-1946. DOI: http://dx.doi.org/10.1002/ esp.1506

Spelman, H., 1979: Final Report. Geology, hydrogeology and engineering geological features of the Serayu River Basin, Central Java, Indonesia.- Netherlands Universities Foundation for International Cooperation, Serayu Valley Project: Volume 4.

Sweeting, M.M., 1972: Karst Landforms.- Macmillan, pp. 362, London.

Sweeting, M.M., 1995: Karst in China: Its Geomorphology and Environment.- Springer, pp. 265, Berlin.

Telbisz, T., Dragušica, H., \& B. Nagy, 2009: Doline Morphometric Analysis and Karst Morphology of Biokovo Mt (Croatia) Based on Field Observations and Digital Terrain Analysis.- Hrvatski Geografski Glasnik, 71, 2, 5-22.

Tjia, H.D., 2013: Morphostructural Development of Gunungsewu Karst, Jawa Island Perkembangan Morfostruktur Kars Gunungsewu Di Pulau Jawa.- Indonesian Journal of Geology, 8, 2, 75-88. DOI: http:// dx.doi.org/10.17014/ijog.v8i2.157

Urushibara, Y.K. \& M. Yoshino, 1997: Palaeoenvironmental Change in Java Island and Its Surounding Areas.- Journal of Quarternary Science, 12, 5, 435442. DOI: http://dx.doi.org/10.1002/(sici)10991417(199709/10)12:5<435::aid-jqs325>3.0.co;2-e

Widyastuti, M. \& E. Haryono, 2016: Water Quality Characteristics of Jonge Telaga (Doline Pond) as Water Rerources for the People of Semanu District Gunungkidul Regency.- Indonesian Journal of Geography, 48, 2, 157-167. DOI: https://doi.org/10.22146/ ijg. 17595

Williams, P.W., 1971: Illustrating Morphometric Analysis of Karst with Example from New Guinea.- Z. Geomorphologie, 14, 40-61. 